\title{
The Souls of White Folk: W.E.B. Du Bois's Critique of White Supremacy and Contributions to Critical White Studies
}

\section{Reiland Rabaka \\ University of Colorado at Boulder}

White folks know niggers talk, an they dont mind jes so long as nothing comes of it, so here goes. (Toomer, 1993, p. 90)

This race talk is, of course, a joke, and frequently it has driven me insane and probably will permanently in the future; and yet, seriously and soberly, we black folk are the salvation of mankind.

(Du Bois, 1995, p.470)

\section{Anti-Racism and Radical Politics, White Supremacy and Critical Social Theory}

Traditionally "white supremacy" has been treated in race and racism discourse as white domination of and white discrimination against non-whites, and especially blacks. It is a term that often carries a primarily legal and political connotation, which has been claimed time and time again to be best exemplified by the historic events and contemporary effects of: African holocaust, enslavement and colonization; the "failure" of reconstruction, the ritual of lynching and the rise of Jim Crow segregation in the United States; and, white colonial and racial rule throughout Africa, and especially apartheid in South Africa (Cell, 1982; Fredrick- 
son, 1981; Marx, 1998; Shapiro, 1988). Considering the fact that state-sanctioned segregation and black political disenfranchisement have seemed to come to an end, "white supremacy" is now seen as classical nomenclature which no longer refers to contemporary racial and social conditions. However, instead of being a relic of the past that refers to an odd or embarrassing moment in the United States and South Africa's (among many other racist nations and empires') march toward multicultural democracy, it remains one of the most appropriate ways to characterize current racial national and international conditions. Which, in other words, is to say that white supremacy has been and remains central to modernity (and "postmodernity") because "modernity" (especially in the sense that this term is being used in European and American academic and aesthetic discourse) reeks of racial domination and discrimination (Coldberg, 1990, 1993; Mills, 1998, 2003; Outlaw, 1996, 2005). It is an epoch (or aggregate of eras) which symbolizes not simply the invention of race, but the perfection of a particular species of global racism: white supremacy. Hence, modernity is not merely the moment of the invention of race, but more, as Theodore Allen $(1994,1997)$ argues in The Invention of the White Race, it served as an incubator for the invention of the white race and a peculiar pan-Europeanism predicated on the racial ruling, cultural degradation and, at times, physical decimation of the life-worlds of people of color.

In "The Souls of White Folk," which was initially published in the Independent in 1910, then substantially revised and published in Darkwater in 1920, Du Bois (1995) stated, "Everything considered, the title to the universe claimed by White Folk is faulty" (p. 454). Long before the recent discourse on critical race theory and critical white studies, Du Bois called into question white superiority and white privilege, and the possibility of white racelessness and/or white racial neutrality and universality. He was one of the first theorists to chart the changes in race relations from de jure to de facto forms of white supremacy, referring to it, as early as 1910, as "the new religion of whiteness" (p. 454).

White supremacy would or will not end unless and until the values and views endemic to it and associated with it were or are rejected and replaced by radical - and, I am wont to say, following the critical pedagogue Peter McLaren (1997), "revolutionary" multicultural and uncompromising ethical views and values. The rejection of white supremacy and the replacement of white supremacist views and values involves not only blacks and other people of color, but whites as well. As the examples of the Emancipation Proclamation, Reconstruction, and the Civil Rights movement indicate, changes in the law and its interpretation and application do not always translate into racial justice and social transformation (Berry, 1994; Higginbotham, 1978, 1996; King, 1995). White supremacist social views and values linger long after amendments have been made and laws 
changed. Therefore, law-focused critical white studies, and critical race theory provide at best only part of the picture (Bonilla-Silva, 2001; Delgado, 1995; Delgado \& Stefancic, 1997; Essed \& Goldberg, 2001).

The conception and critique of white supremacy that I develop here does not seek to sidestep socio-legal race discourse as much as it intends to supplement it with Du Bois and others' work in radical politics and critical social theory (Clark \& O’Donnell, 1999; Doane \& Bonilla-Silva, 2003; Hill, 1997; Nakayama \& Martin, 1999; Sefa Dei, Karumanchery \& Karumanchery-Luik, 2004; Rabaka, 2007, forthcoming). One of the main reasons this supplemental approach to critical white studies (and critical race theory) is important is because typically legal studies of race confine theorists to particular national social and political arenas, which is problematic considering the fact that white supremacy is an international or global racist system (Mills, 1999). Du Bois (1995) declared, "whiteness is the ownership of the earth forever and ever, Amen!" (p. 454). Here he is sardonically hinting at the cardinal difference between white supremacy and most other forms of racism: its worldwide historical, cultural, social, political, legal, and economic influence and impact. White supremacy serves as the glue that connects and combines racism to colonialism, and racism to capitalism. It has also been illustrated that it exacerbates sexism by sexing racism and racing sexism, to put it unpretentiously. Thus, white supremacy as a global racism intersects and interconnects with sexism, and particularly patriarchy as a global system that oppresses and denies women's human dignity and right to be humanly different from men, the ruling gender (Davis, 1981, 1989, 1998; hooks, 1981, 1984, 1991, 1995; Lorde, 1984; Rabaka, 2003c, 2004).

With regard to Du Bois's critique of white supremacy, it is not simply a global and social phenomenon, but a personal and political one as well. That is to say that for Du Bois white supremacy is simultaneously systemic and systematic, and also a matter of racist cultural mores and manners, which teeter-totter between idealist, materialist, and constructionist accounts of race. An idealist account of race says simply (or, not so simply) that white racism against non-whites, and especially blacks, is not so much a matter of race as it is of culture. Racial idealists argue that European culture and its pre-colonial history of color-symbolism and religious views - such as, Europeans' conceptions of themselves as "civilized" whites and non-whites as "wild," "savage" Others; the positive and negative associations regarding the colors white and black; and, the ways in which their racist cultural interpretations of Christianity support not only the white/black color valuations and devaluations but the "civilize and Christianize" missions of European colonialism and imperialism - set the stage for what would later become racism and white supremacy (Fredrickson, 1987; Horsman, 1986; Jordan, 1977).

Materialist accounts of race, which are primarily inspired by Marxist 
theory, maintain that racism does not have to do with culture as much as it does political economy. Europeans needed a cheap labor force to extra-exploit and work their newly and imperially acquired continents, countries, colonial settlements and plantations. For the racial materialists it was not about religion or civilization or science, but an economics and politics reduced to its lowest and most racist level (Cox, 1959, 1987; Genovese, 1965, 1969, 1974, 1979; C.L.R. James, 1963, 1995, 1996; E. Williams, 1966). Finally, racial constructionists contend that race is an outgrowth of human beings' inherent ethnocentrism, but that racism is a result of Europe's push for global dominance. In this view, no matter who invented race, its reasons for origination, and whether it is scientifically sound, it is an artifact that most modern (and "postmodern") human beings use, either consciously or unconsciously, to make interpersonal, socio-cultural and politicoeconomic decisions. "Whites" and "non-whites" do not exist prior to the imperial expansion that helped to birth, raise and rear European modernity. But, this is all beside the point to the constructionists. What is relevant is the invention of whiteness and its classical and contemporary uses and abuses, and the ways it has evolved over several centuries, transitioning from de jure to de facto form, and transforming the racial rules and ethnic ethics of who counts as "white" and "nonwhite" (Allen, 1994, 1997; Goldberg, 1993, 1997, 2001; Harris, 1999; Lopez, 1995, 1996; Omi \& Winant, 1994; Roediger, 1994, 1999).

\section{Critical Race Theory, Critical Social Theory, and "The Souls of White Folk"}

Du Bois's writings on race do not fit nicely and neatly into any of the aforementioned accounts of race. As even a cursory review of his concepts of race and critiques of racism reveal, at different intervals throughout his long life and career he harbored what would currently be considered aspects of each of the three accounts of race discussed above. For Du Bois, as I intimated earlier, white supremacy was not simply a global and social phenomenon, but a personal and political one as well. Hence, his assertion, in "The Souls of White Folk": "The discovery of personal whiteness among the world's peoples is a very modern thing" (1995, p. 453). Take special note of the connection Du Bois makes between "personal whiteness" and "modernity," to use the latter term loosely. His dialectical approach to white supremacy accents its interconnections with other systems of oppression because in his critical socio-theoretical framework racism is one of several "very modern" intersecting hegemonic variables. But, it is white supremacy's globality, the fact that it is a racist global system or "racial polity," as Charles Mills (1999) maintains, that marks it for much-needed critical theoretical consideration. 
In his critique of the global aspects of white supremacy, Du Bois engaged its origins and evolution(s), locating its genesis, uniqueness and ubiquitousness in European imperial global expansion, domination, and colonization (Rabaka, 2003a, 2005). What distinguished white supremacy from local, national and regional racisms, such as those that exist between certain non-white groups, is its international imperial nature and modern world-historic influence and effects. At the heart of the history of white supremacy, as quiet as it is kept, is a prolonged practice and promotion of an extremely acute form of cultural racism and cultural theft. For Du Bois (1995), whites were "super-men" and "world-mastering demi-gods" with "feet of clay" (p. 456). By which he meant, whites, with all their claims of superiority and "super-humanity," were or appeared super-strong because they built their empire(s) on the inventions and innovations, and on the cultures and contributions of the people of color they colonized (p. 457). But, as the "super-men" with "feet of clay" comment reveals, the colored and colonized were well aware of whites' weakness(es), of their Achilles' heel(s): Their imperial push for global domination, that is, their centuries-spanning project(s) of setting up systems of oppression unwittingly and ironically created intra-imperial cultural tensions, racist sibling rivalries amongst themselves, and also created the context and laid the foundation for the very anti-imperial colored/colonized hammer that would smash the imperial white "super-men's" "feet of clay." In "The Souls of White Folk," Du Bois (1995) asserted:

The greatness of Europe has lain in the width of the stage on which she has played her part, the strength of the foundations on which she has builded, and a natural, human ability no whit greater (if as great) than that of other days and races. In other words, the deeper reasons for the triumph of European civilization lie quite outside and beyond Europe - back in the universal struggles of all mankind. Why, then, is Europe great? Because of the foundations which the mighty past have furnished her to build upon: the iron trade of ancient, black Africa, the religion and empire-building of yellow Asia, the art and sciences of the "dago" Mediterranean shore, east, south, and west, as well as north. And, where she had builded securely upon this great past and learned from it she has gone forward to greater and more splendid human triumph; but where she has ignored this past and forgotten and sneered at it, she has shown the cloven hoof of poor, crucified humanity - she has played, like other empires gone, the world fool! If, then, European triumphs in culture have been greater, so, too, may her failures have been greater. (p. 459)

Here Du Bois notes major "gifts" or contributions to culture and civilization that various people of color have made throughout human history, many of them in their pre-colonial (or, rather pre-European colonial) periods. He does not diminish or attempt to downplay the "greatness of Europe," but observes that 
"the triumph of European civilization lie quite outside and beyond Europe." From Du Bois's (1986) racial frame of reference, each ethnocultural group or, rather, each "race" has a "great message...for humanity" (p. 820). He was extremely confident in the greatness of Africana peoples' past and present gift(s) and spirit of giving, even in the face of and often, it seemed, in spite of their endurance and experience of holocaust, enslavement, colonization, segregation, and so forth.

One of the main reasons Du Bois believed black folk were uniquely "gifted," and their "gifts" were especially valuable with regard to world culture and civilization was because their anti-racist (and anti-colonial) struggle strategies and tactics had historically and consistently been different from those of any other human group. This is so, in Du Bois's cultural gift theory, on account of the fact that in white supremacist social hierarchy Africans are the antithesis of Europeans, or blacks are the subhuman opposite of white humans. Again, it is a cultural as opposed to biological conception of race that Du Bois opts for to critique and combat white supremacy and advocate Africana unity. In The Education of Black People, he stated: "Biologically we are mingled of all conceivable elements, but race is psychology, not biology; and psychologically we are a unified race with one history, one red memory, and one revolt" (1973, p. 100).

His "gift theory," like his overall philosophy of race, hinged on a conception of culture that was increasingly informed by continental and diasporan African history, radical politics, and social theory. Just as he rhetorically asked and answered the question, "What, then, is a race?," in "The Conservation of Races," Du Bois's burgeoning anti-biological and pro-sociocultural conception of race critically queried culture. If race is not biological and it is indeed cultural, as Du Bois came to claim, then, one of the first things we need to find out is how he conceived of culture. I will leave it to Du Bois to elaborate his philosophy of culture and its connection(s) to his philosophy of race. In The Education of Black People, he rhetorically queried, "What is a culture?" Then, he contended:

It is a careful Knowledge of the Past out of which the group as such has emerged: in our case a knowledge of African history and social developmentone of the richest and most intriguing which the world has known. Our history in America, north, south and Caribbean, has been an extraordinary one which we must know to understand ourselves and our world. The experience through which our ancestors have gone for four hundred years is part of our bone and sinew whether we know it or not. The method which we evolved for opposing slavery and fighting prejudice are not to be forgotten, but learned for our own and others' instruction. We must understand the differences in social problems between Africa, the West Indies, South and Central America, not only among the Negroes but those affecting Indians and other minority groups. Plans for the future of our group must be built on a base of our problems, our dreams and frustrations; they 
cannot stem from empty air or successfully be based on the experiences of others alone. (1973, pp. 143-144)

Beginning with "a careful Knowledge of the Past," both continental and diasporan, Du Bois's definition of culture takes a hard turn toward "experience" and he states that the lived-experiences of "our ancestors" are "part of our bone and sinew whether we know it or not." In fact, "we must know" "[o]ur history" in Africa, the Americas - for Du Bois this is the United States north and south, Central and South America - and the Caribbean, in order to "understand ourselves and our world." So, besides being grounded historically in continental and diasporan African lived-experiences, Du Bois's concept of culture gravitates and grows toward an experiential and existential exploration and explanation of Africana life-worlds, of Africana actualities, past and present. In other words, if indeed culture has to do with "a careful Knowledge of the Past out of which the group as such has emerged," the "Past" in Du Bois's thinking was much more than historical, it was also cultural.

Culture is the totality of thought and practice by which a people creates itself, celebrates, sustains and develops itself and introduces itself to history and humanity. Moreover, culture is the thought-, belief- and value- systems and traditions that people create, extend and expand to not only make sense of the world, but also to alter it in their own and others' best interests. That is why Du Bois asserted above: "The method which we evolved for opposing slavery and fighting prejudice are not to be forgotten, but learned for our own and others' instruction." Here he is suggesting that classical Africana anti-racist and anti-colonial liberation thought and practice in the fight against white supremacy ("slavery" and "prejudice") could and should be instructional for contemporary Africana and other oppressed people. In Du Bois's gift theory, this is one of Africana peoples' greatest gifts and/or cultural contributions: their spirit of struggle, sacrifice, and service in the interest of social transformation and human liberation.

In "The Conservation of Races," Du Bois (1986) declared: "We believe that the Negro people, as a race, have a contribution to make to civilization and humanity, which no other race can make" (p. 825). He held this belief primarily for two reasons. First, it was based on Africa's past, "one of the richest and most intriguing which the world has known." Most race and/or racist scientists at the turn of the twentieth century either had no knowledge of Africa's past, or they were aware of it and developed their racist theories to counter claims of the greatness of African antiquity. As Du Bois (1995) put it in his classic 1923 essay "The Superior Race": "Lions have no historians" (p. 474). By which he wished to imply that even though the lion is universally revered as the "king of jungle," it is nonetheless an animal and, therefore, has no history and, thus, no need of historians. It is only human beings who can make history and create culture, and in 
a white supremacist world blacks are not human, but subhuman. Therefore, the history and culture that Africans did in fact produce in ancient epochs, or in the pre-colonial period, is viewed as either influenced by or derivative of European culture, or a "primitive" attempt to imitate and emulate European culture, usually Greco-Roman culture. Du Bois's critique of and counter to these claims can be found in his watershed works in the area of African historiography. For example, works such as, The Negro (1915 [2001]), Africa, Its Geography, People and Products (1930), Africa-Its Place in Modern History (1930), Black Folk Then and Now: An Essay on the History and Sociology of the Negro Race (1939), Color and Democracy: Colonies and Peace (1945), The World and Africa (1947 [1965]), and Africa: An Essay Toward a History of the Continent of Africa and Its Inhabitants (1961).

The second reason Du Bois believed that Africana peoples had a significant contribution to make to culture and civilization was because of their endurance and experiences of holocaust, enslavement, colonization, segregation and so on, had "gifted" them with "second-sight," as he put it in The Souls of Black Folk (1986, p. 364). This "second-sight" enabled black folk to see things that others could not on account of the specificities of their historicity. That is to say, Du Bois believed that blacks' contemporary "gift" to culture and civilization had to do with their particular and peculiar position in and struggle(s) against one of the major systems of oppression plaguing people in the modern moment: white supremacy. Du Bois's belief that Africana people have a "great message...for humanity" led him to a life-long critique of white supremacy that is best exemplified by works such as: "Race Friction Between Black and White" (1908), "The Souls of White Folk" (1910), "Of The Culture of White Folk" (1917), "White CoWorkers" (1920), “The Souls of White Folk” (1920), “The Superior Race” (1923), "The White Worker" (1935), "The White Proletariat in Alabama, Georgia, and Florida" (1935), “The White World" (1940) and "The White Folk Have a Right to Be Ashamed" (1949). Of these works, "The Souls of White Folk," published in Darkwater: Voices Within the Veil (1920), and which recasts and combines Du Bois's 1910 essay by that name and his freshly penned piece, "Of the Culture of White Folk" (1917), offers his most sustained and sophisticated statement against white supremacy, as it not only critiques white supremacy, but represents and registers as one of the first attempts to expose white supremacy's influences on and interconnections with other systems of oppression, such as colonialism and capitalism.

As his philosophy of race and critique of white supremacy evolved, so too did Du Bois's gift theory. It began innocently enough as a claim that Africana people, "as a race, have a contribution to make to civilization and humanity, which no other race can make" (1986, p. 825). Then, it grew gradually into a charge to 
contemporary Africana people to emulate and audaciously endeavor to surpass their ancestors' contributions to culture and civilization. In "The Conservation of Races," Du Bois (1986) declared:

Manifestly some of the great races of today - particularly the Negro race - have not as yet given to civilization the full spiritual message which they are capable of giving. I will not say that the Negro race has as yet given no message to the world, for it is still a mooted question among scientists as to just how far Egyptian civilization was Negro in its origin; if it was not wholly Negro, it was certainly very closely allied. Be that as it may, however, the fact still remains that the full, complete Negro message of the whole Negro race has not as yet been given to the world. (pp. 819-820)

From Du Bois's optic, blacks had been unable to give "civilization the full spiritual message which they are capable of giving" primarily because of white supremacy and its enormous and unfathomable effects on Africana life-worlds and lived-experiences. His early uncertainty regarding the African origins of ancient Egyptian civilization was laid to rest as a result of the research of Franz Boas, Leo Frobenius, and Harry Johnston, among others. If Egypt, undoubtedly one of the greatest classical civilizations, was African or, at the least, initiated by Africans - as Du Bois documented in The Negro, Black Folk Then and Now, and The World and Africa - then, it would be a great disservice to modern Africana people to argue that they have "given no message to the world." As he studied and learned more of Africa's ancient and pre-colonial past, Du Bois's gift theory shifted its emphasis from Africana people giving "the full, complete Negro message...to the world," to accenting and highlighting classical African contributions to culture and civilization with an eye toward: first, confronting and combating the white supremacist theses of, of course, white superiority and black inferiority and, also, blacks' purported lack of history and culture; second, providing contemporary Africana people with classical Africana cultural paradigms and traditional motifs; and, finally, offering a caveat to continental and diasporan Africans that their task is not so much to give the definitive Africana message to the world (something, on second thought, that may never really be possible), but to contribute to and continue the Africana struggle for freedom and justice in their age and leave a legacy for succeeding generations.

Generic racism, if there is such a thing, essentially entails racial domination and discrimination. White supremacy does not simply racially oppress, as Du Bois asserted above. Being the fraternal twin (or, at the least, a sibling of some sort) of capitalism it racially oppresses in the interest of nonpareil racialized economic exploitation. It symbolizes the intensification of economic exploitation by adding a racist dimension to capitalist greed and colonial gain. Hinging on a 
diabolical dialectic that sees whites as superior and non-whites as inferior, white supremacy consumes the world of color and claims non-whites' contributions to human culture and civilization as European or white contributions to culture and civilization. This is so because from the white supremacist point of view, nonwhites do not now and have never possessed culture and civilization and, therefore, could not possibly contribute to the (re)construction of something they do not now and have never possessed. Further, white supremacy enables and utterly encourages whites to theoretically and culturally loot the knowledge banks and cultural treasure troves of the colored world, similar to the way whites did when they established racial colonialism and colonial capitalism, because it is a global system that rewards based on the embrace of white hegemonic views and values, white conquest and racialized colonization.

Moving beyond a strictly materialist (politico-economic and/or class-centered) account of race and racism, and hitting at the heart of white supremacy, Du Bois (1995), in "The Souls of White Folk," queried the "colored world" and those whites who would open themselves to moral and materialist questions: "How many of us today fully realize the current theory of colonial expansion, of the relation of Europe which is white, to the world which is black and brown and yellow? Bluntly put, that theory is this: It is the duty of white Europe to divide up the darker world and administer it for Europe's good" (p. 459). Part of Du Bois's critique of white supremacy reveals his reliance on racial materialist arguments, where the other portion of his critique revolves around his own homegrown cultural nationalism, which was more often later in his life, what I will term, a cultural internationalism that sought to accent and highlight commonalities and kinships amongst people of color based on their endurances and experiences of, and struggles against European imperial expansion and all out white (cultural, social, political, legal, educational, religious, aesthetic and economic) domination and discrimination. Du Bois's critical comments in "The Souls of White Folk" deserve quotation at length, as his argument is elaborated throughout several carefully constructed paragraphs that poignantly capture the crux of his critique of white supremacy:

The European world is using black and brown men for all the uses which men know. Slowly but surely white culture is evolving the theory that "darkies" are born beasts of burden for white folk. It were silly to think otherwise, cries the cultured world, with stronger and shriller accord. The supporting arguments grow and twist themselves in the mouths of merchant, scientist, soldier, traveler, writer, and missionary: Darker peoples are dark in mind as well as in body; of dark, uncertain, and imperfect descent; of frailer, cheaper stuff; they are cowards in the face of mausers and maxims; they have no feelings, aspirations, and loves; they are fools, 
illogical idiots — "half-devil and half-child."

Such as they are civilization must, naturally, raise them, but soberly and in limited ways. They are not simply dark white men. They are not "men" in the sense that Europeans are men. To the very limited extent of their shallow capacities lift them to be useful to whites, to raise cotton, gather rubber, fetch ivory, dig diamonds - and let them be paid what men think they are worth - white men who know them to be well-nigh worthless.

Such degrading of men by men is as old as mankind and the invention of no one race or people. Ever have men striven to conceive of their victims as different from the victors, endlessly different, in soul and blood, strength and cunning, race and lineage. It has been left, however, to Europe and to modern days to discover the eternal world-wide mark of meanness - color!

Such is the silent revolution that has gripped modern European culture in the later nineteenth and twentieth centuries. Its zenith came in Boxer times: White supremacy was all but world-wide, Africa was dead, India conquered, Japan isolated, and China prostrate, while white America whetted her sword for mongrel Mexico and mulatto South America, lynching her own Negroes the while. (p. 460)

The "civilized" (read: whites) are simultaneously a race in a socio-cultural and politico-economic sense, though they do not think of themselves in racial terms, and they throw temper tantrums when they are thought of in racial terms or, as being racialized or raced. They can steal and kill the "uncivilized" (read: people of color) without regard to rank or reason, and they can at any moment change the rules of the racial hierarchy and racial history because they alone are decidedly and definitively the authors of human culture and civilization, and most certainly the architects of science and technology. As Du Bois demonstrates above, white supremacy is not simply about racial domination and discrimination. Which is to say, white supremacy cannot quickly be reduced to racism, and especially as it is understood in contemporary racial discourse. Much more, white supremacy robs the raced or people of color of their right to be human, of their right to self-definition and self-determination. It reduces human beings to the status of things, which is one of the reasons, as Frantz Fanon observes in The Wretched of the Earth, when they are discussed in the discursive arenas of the white world, both academic and non-academic, people of color are referred to, (re)presented and (re)imagined in "zoological terms" - in the terms in which animals are discussed, dissected and dominated. Fanon (1968) famously wrote:

In fact, the terms the [white colonial] settler uses when he mentions the native [the raced, or the colored] are zoological terms. He speaks of the yellow man's reptilian motions, of the stink of the native quarter, of 
breeding swarms, of foulness, of spawn, of gesticulations. When the settler seeks to describe the native fully in exact terms he constantly refers to the bestiary. (p. 42)

\section{Critical White Studies and the Riddle(s) of Critical Race Theory}

Du Bois's critique of white supremacy also hits head-on the issue of white personhood and black (or people of color) subpersonhood. He asserted: "They [the colored and colonized] are not simply dark white men. They are not 'men' in the sense that Europeans are men." Whiteness and maleness are prerequisites for personhood in the world that modernity made. A person, in this world, is one who is rational, self-directing and morally and legally equal with a white male. Since white males created the laws of this world, none but white males are equal and given moral, legal and extralegal consideration. Therefore, as the Dred Scott decision demonstrates, "a black man has no rights which a white man is legally bound to respect" (see Dred Scott, 1857, pp. 403-407). White rights are intimately intertwined with the denial of black rights. Or, to put it another way, white personhood is inextricable from black subpersonhood. In The Racial Contract, Charles Mills (1997) contends:

Whiteness is defined in part in respect to an oppositional darkness, so that white self-conceptions of identity, personhood, and self-respect are then intimately tied up with repudiation of the black Other. No matter how poor one was, one was still able to affirm the whiteness that distinguished one from the subpersons on the other side of the color line. (pp. 58-59)

And, who or what are these "human things," to borrow a phrase from Du Bois's (1995) discourse, on the "other side of the color line" (p. 456)? Mills (1997) maintains:

Subpersons are humanoid entities who because of racial phenotype/genealogy/culture, are not fully human and therefore have a different and inferior schedule of rights and liberties applying to them. In other words, it is possible to get away with doing things to subpersons that one could not do to persons, because they do not have the same rights as persons. (p. 56)

Even in its mildest and most unconscious forms, white supremacy is one of the extremest and most vicious human rights violations in history because it plants false seeds of white superiority and black inferiority in the fertile ground of the future. It takes human beings and turns them into the subhuman things, making them colored means to a white imperial end. Du Bois's critique of white supremacy then, registers as not only a radical criticism of an increasingly illusive 
and nebulous racism, but an affirmation of black humanity and an epoch-spanning assertion of Africana and other oppressed peoples' inherent right to human and civil rights.

\section{Acknowledgements}

I am indelibly indebted to several intellectual-activists who have contributed (either directly or indirectly) to my conception(s) of philosophy of race, sociology of race, critical race theory, critical social theory, and radical politics. A humble and heartfelt asante sana (many thanks) goes to: Marilyn Giles, Lucuis Outlaw, Kristine Lewis, De Reef Jamison, Rhonda Tankerson, Mark Christian, Toroitich Cherono, Anthony Lemelle, Lamya Al-Kharusi, Kimberly Marshall, and my colleagues at the Center for Studies of Ethnicity and Race in America (CSERA) at the University of Colorado at Boulder.

\section{References}

Allen, T.W. (1994). The invention of the White race, volume 1. New York: Verso. . (1997). The invention of the White race, volume 2. New York: Verso.

Berry, M.F. (1994). Black resistance, White law: A history of constitutional racism in America. New York: Allen Lane.

Bonilla-Silva, E. (2001). White supremacy and racism in the post-Civil Rights era. Boulder, CO: Lynne Rienner.

Cell, J.W. (1982). The highest stage of White supremacy: The origins of segregation in South Africa and the American South. Cambridge: Cambridge University Press.

Clark, C., and O'Donnell, J. (Eds.). (1999). Becoming and unbecoming white:

Owning and disowning a racial identity. Westport, CT: Bergin \& Garvey.

Cox, O. C. (1959). Caste, class, and race: A study in social dynamics. New York: Monthly Review Press. . (1987). Race, class, and the world system(H. M. Hunter and S.Y. Abraham,

Eds.). New York: Monthly Review Press. 
Davis, A.Y. (1981). Women, race and class. New York: Vintage.

. (1989). Women, culture, and politics. New York: Vintage.

(1998). The Angela Y. Davis Reader (J.A. James, Ed.). Malden,

MA: Blackwell.

Delgado, R. (Ed.). (1995). Critical race theory: The cutting edge. Philadelphia:

Temple University Press.

Delgado, R., and Stefancic, J. (Eds.). (1997). Critical white studies: Looking behind the mirror. Philadelphia: Temple University Press.

Doane, A., and Bonilla-Silva, E. (Eds.). (2003). White out: The continuing significance of racism. New York: Routledge.

Dred Scott vs. Sanford 1857: 60 US (19 How.).

Du Bois, W.E.B. (1930a). Africa, its geography, people and products. Girard, Kansas: Haldeman-Julius.

. (1930b). Africa, its place in modern history. Girard, Kansas: Haldemen-Julius. . (1939). Black folk then and now: An essay in the history and sociology of the Negro race. New York: Henry Holt.

. (1945). Color and democracy: Colonies and peace. New York:

Hartcourt Brace.

. (1961). Africa: An essay toward a history of the continent of Africa and its inhabitants. Moscow: Soviet Institute of African Studies.

. (1965). The world and Africa: An inquiry into the part which Africa has played in world history. New York: International Publishers.

(1969). Darkwater: Voices from within the veil. New York: Schocken. . (1970). The gift of Black folk: The Negro in the making of America. New York: Simon \& Schuster.

(1973). The education of Black people: Ten critiques,1906-1960(H. Ap- 
theker, Ed.). New York: Monthly Review Press.

___. (1986). Du Bois: Writings (N. I. Huggins, Ed.). New York:

Library of America Press.

(1995). W.E.B. Du Bois reader (D. L. Lewis, Ed.). New York: Henry Holt. (1997). The souls of Black folk (R. Gooding-Williams and D.W. Blight,

Eds.). Boston: Bedford Books.

. (2001). The Negro. Mineola, NY: Dover.

. (2004). The social theory of W.E.B. Du Bois (P. Zuckerman, Ed.).

Thousand Oaks: Sage.

Essed, P., and Goldberg, D.T. (Eds.). (2001). Race critical theories: Texts and contexts. Malden: Blackwell.

Fanon, F. (1967). Black skin, White masks. New York: Grove.

(1968). The wretched of the earth. New York: Grove.

Fredrickson, G. (1981). White supremacy: A comparative study in American and South African history. New York: Oxford University Press.

___. (1987). The Black image in the White mind: The debate on Afro-American character and destiny, 1817-1914. Hanover, NH: Wesleyan University Press.

Genovese, E.D. (1965). The political economy of slavery: Studies in the economy and society of the slave South. New York: Pantheon.

. (1969). The world the slaveholders made: Two essays in interpretation.

New York: Pantheon.

(1974). Roll, Jordan, roll: The world the slaves made. New York: Vintage. (1979). From rebellion to revolution: Afro-American slave revolts in the making of the modern world. Baton Rouge: Louisiana State University Press. Goldberg, D.T. (Ed.). (1990). Anatomy of racism. Minneapolis: University of Minnesota Press. 
. (1993). Racist culture: Philosophy and the politics of meaning. Cambridge:

B Blackwell.

. (Ed.). (1994). Multiculturalism: A critical reader. Cambridge: Blackwell.

. (1997). Racial subjects: Writing on race in America. New York: Routledge.

. (2001). The racial state. Malden, MA: Blackwell.

Goldberg, D.T., and Solomos, J. (Eds.). (2002). A companion to racial and ethnic studies. Malden: Blackwell.

Harris, L. (Ed.). (1999). Racism: Key concepts in critical theory. Amherst, NY: Humanity Books.

Higginbotham, A.L., Jr. (1978). In the matter of color: Race and the American legal process - The colonial period. New York: Oxford University Press. . (1996). Shades of freedom: Racial politics and presumptions of the American legal process. New York: Oxford University Press.

Hill, M. (Ed). (1997). Whiteness: A Critical Reader. New York:

New York University Press.

hooks, bell. (1981). Ain't I a woman: Black women and feminism. Boston: South End.

__-_ (1984). Feminist theory: From margin to center. Boston: South End. . (1991). Black looks: Race and representation. Boston: South End. . (1995). Killing rage: Ending racism. New York: Henry Holt.

Hornsman, R. (1986). Race and manifest destiny: Origins of American racial Anglo-saxonism. Cambridge, MA: Harvard University Press.

James, C.L.R. (1963). The Black Jacobins: Toussaint L'Ouverture and the San Domingo revolution. New York: Vintage Books. . (1995). A history of pan-African revolt. Chicago: Charles H. Kerr Publishing. 
(1996). C.L.R. James on the "Negro Question" (S. McLemee, Ed.). Jackson: University of Mississippi Press.

Jordan, W.D. (1977). White over Black: American attitudes toward the Negro, 1550-1812. Chapel Hill, NC: University of North Carolina Press.

King, D. (1995). Separate and unequal: Black American and the U.S. federal government. Oxford: Clarendon.

Lopez, I.F.H. (1995). The social construction of race. In R. Delgado (Ed.), Critical race theory (pp. 191-203). Philadelphia: Temple University Press.

_-_. (1996). White by law: The legal construction of race. New York: New York University Press.

Lorde, A. (1984). Sister outsider: Essays and speeches by Audre Lorde. Freedom, CA: The Crossing Press Feminist Series.

Marx, A.W. (1998). Making race and nation: A comparison of the United States, South Africa, and Brazil. New York: Cambridge University Press.

McLaren, P. (1997). Revolutionary multiculturalism: Pedagogies of dissent for the new millennium. Boulder, CO: Westview.

Mills, C.W. (1997). The racial contract. Ithaca: Cornell University Press. . (1998). Blackness visible: Essays on philosophy and race. Ithaca:

Cornell University Press.

(1999). The racial polity. In S.E. Babbitt and S. Campbell (Eds.), Racism and philosophy (pp. 13-31, [endnotes] 255-257). Ithaca: Cornel University Press. . (2000). Race and the social contract tradition. Social Identities: A Journal for the Study of Race, Nation and Culture 6, 4, 441-462.

_-_. (2001). White supremacy and racial justice. In J. Sterba (Ed.), Social and political philosophy: Contemporary perspectives (pp. 321-337).

New York: Routledge. 
. (2003). From class to race: Essays in White Marxism and Black radicalism. Lanham, MD: Rowman \& Littlefield.

Nakayama, T.K., and Martin, J.N. (Eds.). (1999). Whiteness: The communication of social identity. Thousand Oaks, CA: Sage.

Omi, M., and Winant, H. (1994). Racial formation in United States: From the 1960's to the 1990's. New York: Routledge.

Outlaw, L.T., Jr. (1996). On race and philosophy. New York: Routledge.

. (2005). Critical Social Theory in the Interest of Black Folk. Lanham, MD:

Rowman \& Littlefield.

Rabaka, R. (2003a). W.E.B. Du Bois's evolving Africana philosophy of education. Journal of Black Studies 33, 4, 399-449.

. (2003b). "Deliberately using the word colonial in a much broader sense":

W.E.B. Du Bois's concept of "semi-colonialism" as critique of and contribution to postcolonialism." Jouvert: A Journal of Postcolonial Studies 7, 2, 1-32. Available on-line at: http://social.chass.ncsu.edu/jouvert/index.htm [23 February 2003].

. (2003c). W.E.B. Du Bois and 'The Damnation of Women': An essay on Africana anti-sexist critical social theory. Journal of African American Studies 7, 2, 39-62.

___. (2004). The souls of Black female folk: W.E.B. Du Bois and Africana anti-sexist critical social theory." Africalogical Perspectives 1, 2, 100-141. (2005). W.E.B. Du Bois and Decolonization: Pan-Africanism, Postcolonialism, and Radical Politics. In James L. Conyers (Ed.), W.E.B. Du Bois, Marcus Garvey, and Pan-Africanism (pp. 123-154). Lewistown, NY: Mellen Press. . (2006a). Africana Critical Theory of Contemporary Society: Ruminations on Radical Politics, Social Theory, and Africana Philosophy. In M.K. Asante and 
M. Karenga (Eds.), The Handbook of Black Studies (pp. 130-152). Thousand Oaks, CA: Sage. . (2006b). The Souls of Black Radical Folk: W.E.B. Du Bois, Critical Social Theory, and the State of Africana Studies." Journal of Black Studies 36 (5), 732-763.

. (2007). W.E.B. Du Bois and the Problems of the Twenty-First Century: An Essay on Africana Critical Theory. Lanham, MD: Lexington Books/Rowman \& Littlefield Publishers.

___. (forthcoming). W.E.B. Du Bois, Black Radical Politics, and the Reconstruction of Critical Social Theory. Lanham, MD: Lexington Books/Rowman \& Littlefield Publishers.

Roediger, D.R. (1994). Towards the abolition of Whiteness: Essays on race, politics, and working-class history. New York: Verso.

(1999). The wages of Whiteness: Race and the making of the American working-class. New York: Verso.

Sefa Dei, G. J., Karumanchery, L., and Karumanchery-Luik, N. (Eds.). (2004). Playing the race card: Exposing white power and privilege. New York: Peter Lang. Shapiro, H. (1988). White violence and Black response: From Reconstruction to Montgomery. Amherst: University of Massachusetts Press.

Toomer, J. (1993). Cane. New York: Liveright.

Williams, E. (1966). Capitalism and slavery. New York: Capricorn Books. 